\title{
Mycobacterium tuberculosis: sometimes, a hidden culprit
}

\author{
Miguel F Carrascosa, ${ }^{1}$ José-Ramón Salcines Caviedes, ${ }^{1}$ Marta C Hoz, ${ }^{1}$ Carmen R Talledo ${ }^{2}$ \\ 'Department of Internal Medicine, Hospital of Laredo, Laredo, Cantabria, Spain; \\ ${ }^{2}$ Ophthalmology Department, University Hospital Marqués de Valdecilla, Santander, Cantabria, Spain
}

Correspondence to Dr Miguel F Carrascosa, miguel.carrascosa@scsalud.es

\section{DESCRIPTION}

A previously healthy 31-year-old woman presented to our emergency department with a 1-month history of fever, non-productive cough, malaise and weight loss. She also reported having had low back and left buttock pain for the last 5 months. Stress tests of the sacroiliac joint, namely the lateral pelvic compression test, the flexion, abduction and external rotation of the hip joint test and the Gaenslen's test (hyperextension of the hip with pelvis fixed by flexion of opposite hip and knee) were positive, that is, they elicited pain on the left sacroiliac joint. Chest radiography performed on admission showed multiple, faint small nodules in both lungs (figure 1A). A subsequent fundus examination revealed a greyishwhite oblong patch with indistinct edges in the right eye (figure 1B), which was ascribed to choroidal tubercle by an ophthalmologist. MRI showed signs of left sacroiliitis with accompanying iliopsoas abscess (figure 1C). The histopathological analysis of the bone marrow biopsy samples from the right iliac crest revealed multiple caseating granulomas with Langhan's-type giant cells (figure 1D). Tuberculin skin test and serology for the human immunodeficiency virus were negative. Specimens from bronchioalveolar lavage fluid, transbronchial biopsy, urine, blood and bone marrow biopsy were negative for acidfast bacilli as well as for Mycobacterium tuberculosis culture and PCR testing. Considering that there was no evidence for other alternative aetiology, disseminated tuberculosis was diagnosed on the basis of miliary chest pattern, choroidal lesion and pathological findings. The patient was treated with antituberculous drugs for 9 months. She had a full clinical and radiological recovery.

Disseminated tuberculosis is uncommon, especially in immunocompetent patients. ${ }^{1}$ The broad spectrum of its
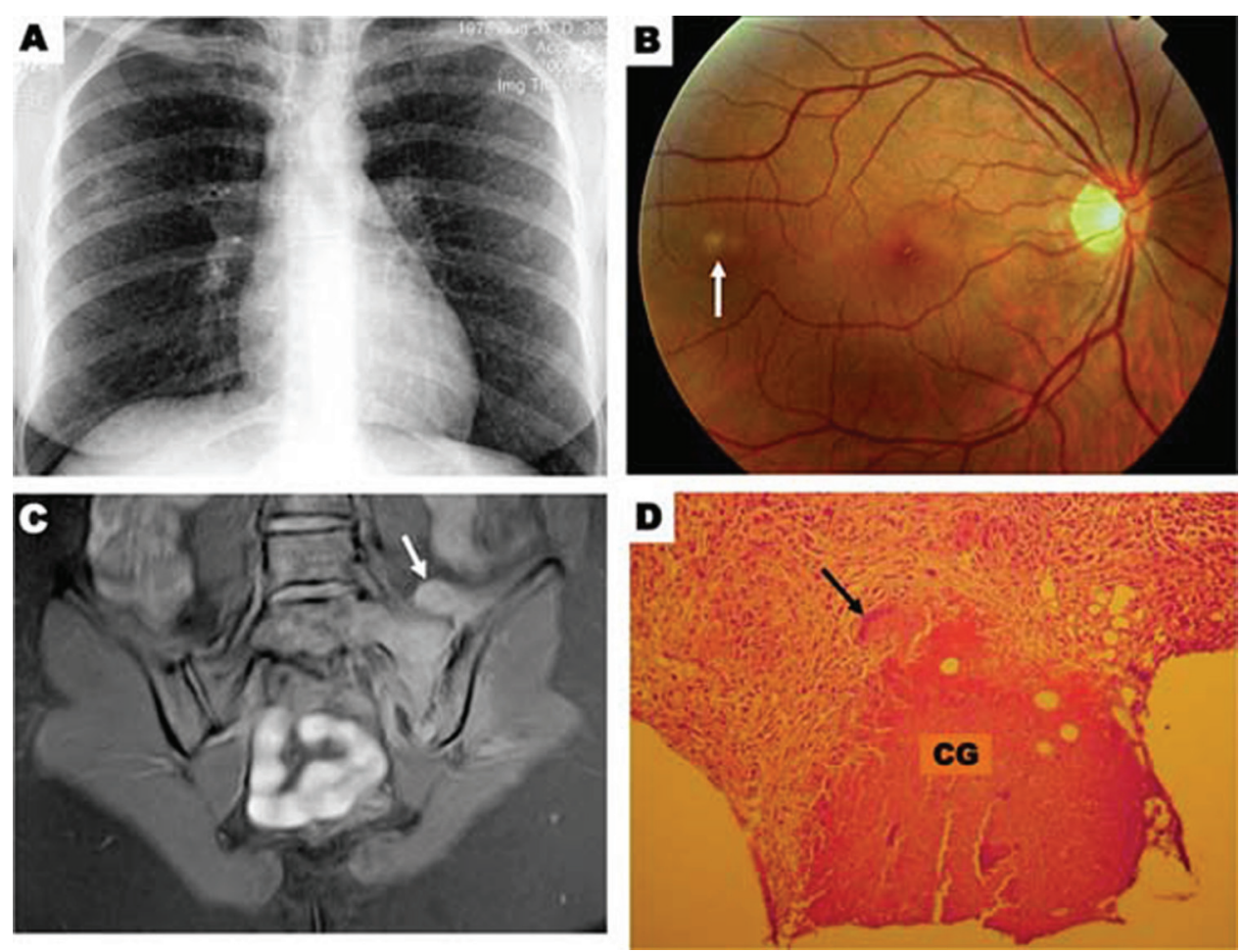

Figure 1 Chest x-ray, revealing a micronodular pattern in both lungs (A). Ophtalmological examination, showing a choroidal tubercle in the left eye (B; arrow). MRI, revealing left sided contrast enhancement in the sacroiliac space and iliac and sacral bones as well as iliopsoas abscess (C; arrow points out to the abscess). Finally, pathological findings in a bone biopsy specimen (D; CG, caseating granuloma; arrow indicates a Langhan's-type giant cell; hematoxylin-eosin stain). 


\section{BMJ Case Reports}

possible presentations makes diagnosis difficult unless clinical suspicion of disease is high. It is well known that, sometimes, current diagnostic tests can not reveal the presence of $M$ tuberculosis. ${ }^{2}$ Since early initiation of treatment is essential to achieve a favourable outcome, clinicians should keep in mind that ophthalmoscopic examination ${ }^{3}$ and histopathologic study ${ }^{2}$ may be important to reach a timely diagnosis of the disease.

\section{REFERENCES}

1. Seif $\mathbf{F}$, Armitage K, Petrozzi M. Unusual presentation of a common disease: disseminated tuberculosis in an immunocompetent patient. Am J Med 2010;123:e5-7.

2. Malipeddi AS, Rajendran R, Kallarackal G. Disseminated tuberculosis after anti-TNFalpha treatment. Lancet 2007;369:162.

3. Sharma SK, Mohan A, Sharma A, et al. Miliary tuberculosis: new insights into an old disease. Lancet Infect Dis 2005;5:415-30.

Competing interests None.

Patient consent Obtained.

This pdf has been created automatically from the final edited text and images.

Copyright 2011 BMJ Publishing Group. All rights reserved. For permission to reuse any of this content visit

http://group.bmj.com/group/rights-licensing/permissions.

BMJ Case Report Fellows may re-use this article for personal use and teaching without any further permission.

Please cite this article as follows (you will need to access the article online to obtain the date of publication).

Carrascosa MF, Caviedes JRS, Hoz MC, Talledo CR. Mycobacterium tuberculosis: sometimes, a hidden culprit. BMJ Case Reports 2011;

10.1136/bcr.06.2011.4383, date of publication

Become a Fellow of BMJ Case Reports today and you can:

- Submit as many cases as you like

- Enjoy fast sympathetic peer review and rapid publication of accepted articles

- Access all the published articles

- Re-use any of the published material for personal use and teaching without further permission

For information on Institutional Fellowships contact consortiasales@bmjgroup.com

Visit casereports.bmj.com for more articles like this and to become a Fellow 